\title{
Dissolved Phosphorus Retention in Buffer Strips: Influence of Slope and Soil Type
}

\author{
T. Darch,* A. Carswell, M. S. A. Blackwell, J. M. B. Hawkins, P. M. Haygarth, and D. Chadwick
}

\begin{abstract}
Phosphorus (P) contributes to eutrophication of surface waters and buffer strips may be implemented to reduce its transfer from agricultural sources to watercourses. This study was conducted to test the hypothesis that soil type and slope influence the retention of dissolved organic $P$ and inorganic orthophosphate in agricultural runoff in 2-m-wide buffer strip soils. A solution, comprised of dissolved orthophosphate and the organic P compounds glucose-1-phosphate, RNA, and inositol hexakisphosphate (1.8 $\mathrm{mg} \mathrm{L}^{-1}$ total $\left.\mathrm{P}\right)$ and a chloride tracer, was applied as simulated overland flow to grassland soil blocks (2 $\mathrm{m}$ long $\times 0.5 \mathrm{~m}$ wide $\times 0.35 \mathrm{~m}$ deep), containing intact clay or loam soils, at slope angles of 2,5 , and $10^{\circ}$. Phosphorus forms were determined in the surface and subsurface flow from the soil blocks. Slope had no significant effect on the hydrological behavior of the soil blocks or on the retention of any form of $P$ at the water application rate tested. The clay soil retained $60 \%$ of the unreactive $P$ and $21 \%$ of the reactive $P$ applied. The loam soil retained $74 \%$ of the unreactive $P$ applied but was a net source of reactive $P$ (the load increased by $61 \%$ ). This indicates leaching of native soil $\mathrm{P}$ or hydrolysis of organic compounds and complicates our understanding of $P$ retention in buffer strip soils. Our results suggest that a 2-m buffer strip may be more effective for reducing dissolved unreactive $P$ transfers to surface waters than for reducing the eutrophication risk posed by dissolved reactive $P$.
\end{abstract}

$\mathrm{P}$ HOSPHORUS $(\mathrm{P})$ is a key nutrient in agriculture, but its transfer to watercourses can contribute to eutrophication of surface waters (Withers and Haygarth, 2007). One method for reducing the delivery of nutrients mobilized from agricultural land to watercourses is the implementation of buffer strips. Although buffer strips have been shown to be effective at retaining diffuse agricultural pollutants (Syversen, 2005), the majority of research supporting this conclusion has focused on particulate $P$ retention, using buffer strips wider than $2 \mathrm{~m}$ (Dorioz et al., 2006). Although the UK Environmental Stewardship Scheme incentivizes landowners to install buffer strips of up to $12 \mathrm{~m}, 2 \mathrm{~m}$ is the minimum width for which they can receive payment (Natural England and Defra, 2013). Although much research into buffer strip effectiveness has been into particulate $\mathrm{P}$ retention, dissolved $\mathrm{P}$ can comprise a significant proportion of the total $\mathrm{P}$ (TP) transferred to watercourses, especially in grassland systems (up to $62 \%$ of the TP in surface runoff and $80 \%$ of TP in subsurface flow) (Heathwaite and Dils, 2000). Furthermore, dissolved forms of $P$ are more bioavailable than particulate forms because plants and microorganisms require $\mathrm{P}$ to be in a dissolved form to utilize it (Rausch and Bucher, 2002). Therefore, it is important to understand how effective a buffer strip is at the minimum width of $2 \mathrm{~m}$ for the retention of dissolved and organic forms of $\mathrm{P}$.

It is generally accepted that the efficiency of a buffer strip for P retention decreases as slope increases (Correll, 1997), especially for sediment and particulate P (Dillaha et al., 1989; Jin and Romkens, 2001), but the effect on dissolved P retention is currently unknown. The effect of soil type on P retention is dependent on soil chemistry and hydrology. Clay soils have a high P sorption capacity compared with other soil types due to a high surface area to volume ratio (Syversen and Borch, 2005) and a higher content of compounds to which $\mathrm{P}$ sorbs, including aluminum ( $\mathrm{Al}$ ) and iron (Fe) oxides (Brady and Weil, 2008). Permeability typically decreases with a change in soil texture from sand to silt to clay, which initially improves $\mathrm{P}$ retention due to the increased contact time between soil and water.

\footnotetext{
T. Darch, A. Carswell, M.S.A. Blackwell, and J.M.B. Hawkins, Rothamsted Research, North Wyke, Okehampton, Devon EX20 2SB, UK; A. Carswell, University of Reading, Whiteknights, Reading, Berkshire, RG6 6AH, UK; P.M. Haygarth, Lancaster Environment Centre, Lancaster University, Lancaster, LA1 4YQ, UK; D. Chadwick, School of Environment, Natural Resources and Geography (SENRGY), Environment Centre Wales, Deiniol Road, Bangor University, Bangor, LL57 2UW, UK. Assigned to Associate Editor Marc Stutter.
}

Abbreviations: HP, hydrolyzable phosphorus; IHP, inositol hexakisphosphate; RP, reactive phosphorus; TP, total phosphorus; UP, unreactive phosphorus. 
However, as permeability decreases, preferential flow through soil macropores and generation of surface runoff increase, which reduces the potential for contact time with soil and hence $\mathrm{P}$ sorption (Glæsner et al., 2011a).

Organic forms of $\mathrm{P}$ have generally been overlooked in research into the transfer of nutrients from land to watercourses (Hoffmann et al., 2009; Ulen et al., 2007). However, plants and microorganisms can utilize organic $\mathrm{P}$ via hydrolysis by phosphatase enzymes (Hayes et al., 1999; Turner and Haygarth, 2005). The results of column studies indicate that organic $P$ is generally more mobile than orthophosphate (Glæsner et al., 2011b; Toor et al., 2005). Organic P compounds, although often grouped together according to similarities in chemical structure (Condron et al., 2005), differ in their sorption to $\mathrm{Al}$ (Guan et al., 2005; Shang et al., 1990) and their mobility in the soil (Anderson and Magdoff, 2005). By combining the results of different labbased studies, it can be hypothesized that the relative strength of sorption of $\mathrm{P}$ groups is inositol phosphates $\sim$ orthophosphate $>$ monoester P > diester P (Anderson and Magdoff, 2005; Guan et al., 2005; Shang et al., 1990). This has implications for water quality because monoester and diester $\mathrm{P}$ are considered to be more bioavailable than the inositol phosphates (Richardson et al., 2001).

Research has shown that dissolved P can comprise 3 to $40 \%$ of surface (Withers et al., 2007) and about $45 \%$ of subsurface (Jensen et al., 2000) TP loads in flow, and organic P comprises 30 to $65 \%$ of soil $\mathrm{P}$ across the world (Condron et al., 2005). The abundance and potential bioavailability of organic $P$ means that it can potentially contribute to eutrophication problems. Consequently, it is important to determine the potential for buffer strips to retain dissolved inorganic and organic $\mathrm{P}$ and the effect slope and soil type have on buffer strip effectiveness. Experiments were performed at the mesocosm scale using intact soil blocks, the slope of which could be manipulated, to test the following hypotheses: (i) the retention of dissolved $\mathrm{P}$ compounds decreases with an increase in soil slope, (ii) $\mathrm{P}$ retention differs with soil type, (iii) the relative retention of $\mathrm{P}$ compounds is in the order inositol hexakisphosphate (IHP) (an inositol phosphate) $\sim$ orthophosphate > glucose-1-phosphate (a monoester) > ribonucleic acid (RNA, a diester), and (iv) a 2-m buffer strip does not sufficiently reduce dissolved $\mathrm{P}$ concentrations to mitigate against water pollution.

\section{Materials and Methods}

\section{Construction of Soil Blocks}

Intact soil blocks measuring $2 \mathrm{~m}$ long $\times 0.5 \mathrm{~m}$ wide $\times 0.35 \mathrm{~m}$ deep were taken, in triplicate, from the topsoil of two sites close to Rothamsted Research, North Wyke (Okehampton, Devon, UK). The first was a clayey, noncalcareous pelo-stagnogley soil (USDA classification typic haplaquept), with an impermeable clay layer beginning at approximately $0.3 \mathrm{~m}$, hereafter referred to as "clay" soil. The second was a typical brown earth soil (USDA classification dystric eutrochrept), hereafter referred to as "loam" soil (Table 1). These soil types were chosen as contrasting examples of soils typical to southwestern England because the loam soil is freely draining, whereas the clay soil is slowly permeable (Harrod and Hogan, 2008). Phosphorus content was not measured in the soil blocks to ensure the soil structure remained intact, but soil samples taken contiguously have been described by Blackwell et al. (2013) and are given in Table 1. Soil blocks were taken from pasture fields that were vegetated with a mixed grass sward (predominantly Lolium perenne L.). Both fields had received standard applications of lime and fertilizer according to RB209 (Defra, 2013) and had been grazed by sheep.

The soil blocks were excavated using a bespoke steel cutter and a mechanical digger. The soil was enclosed in a box made of marine plywood sealed with a hypoxy-resin. To ensure a close fit, the wooden box was constructed around the soil block in situ, and the soil was collected when dry. Compressible foam (20 mm thickness) was glued to the inside surfaces of the box to prevent the occurrence of preferential flow with the shrinking and expansion of the soil block. At one end of the box, slits were cut, and stainless steel gutters were inserted horizontally into the bottom edge of the soil block to enable collection of subsurface flow and $2.5 \mathrm{~cm}$ from the soil surface for collection of surface flow (Fig. 1); both gutters protruded $3 \mathrm{~cm}$ into the soil block. An all-weather silicone sealant (4trade general purpose silicone, shown not to release $\mathrm{P}$ to water) was used to seal joints in the box. Although it was not possible to prevent all leaks, these were quantified for each experimental run and found to be $<5 \%$ of the

Table 1. Properties and phosphorus contents of the loam and clay soils from which the soil blocks were extracted.

\begin{tabular}{lcc}
\hline & Loam & Clay \\
\hline Descriptiont & $\begin{array}{c}\text { Crediton series; reddish-brown very } \\
\text { stony coarse sandy loam }\end{array}$ & Hallsworth series; grayish brown clay \\
Sand $(600 \mu \mathrm{m}-2 \mathrm{~mm}), \%$ & 26 & 1 \\
Sand $(200-600 \mu \mathrm{m}), \%$ & 16 & 3 \\
Sand $(60-200 \mu \mathrm{m}), \%$ & 13 & 8 \\
Silt $(2-60 \mu \mathrm{m}), \%$ & 29 & 50 \\
Clay $(<2 \mu \mathrm{m}), \%$ & 16 & 38 \\
Organic C, $\%$ & 16 & 38 \\
pH $\left(\mathrm{H}_{2} \mathrm{O}\right)$ & 5.8 & 5.3 \\
Water-extractable RP, $\mathrm{mg} \mathrm{P} \mathrm{kg}^{-1} \neq$ & $1.30 \pm 0.00$ & $0.22 \pm 0.00$ \\
Water-extractable TP, $\mathrm{mg} \mathrm{P} \mathrm{kg}^{-1}$ & $2.1 \pm 0.04$ & $0.87 \pm 0.04$ \\
Bicarbonate-extractable, $\mathrm{RP} \mathrm{mg} \mathrm{P} \mathrm{kg}^{-1}$ & $21.43 \pm 0.08$ & $11.16 \pm 1.91$
\end{tabular}

† Soil description, physical properties, organic $\mathrm{C}$, and $\mathrm{pH}$ are typical properties for the soil series. Data for the loam series obtained from Findlay et al. (1984) (depth: 0-23 cm). Data for the clay series obtained from Harrod and Hogan (2008) (depth: 0-27 cm).

‡ Water-extractable reactive P (RP) and total P (TP) and bicarbonate-extractable RP of land representative of where the soil blocks were extracted. Data from Blackwell et al. (2013). 
applied volume of solution/water. The soil blocks were mounted on metal frames, which were designed to enable the slope of the soil block to be altered by raising one end of the block (Fig. 1).

\section{Experimental Design}

Experimental slope angles of 2,5 , and $10^{\circ}$ were chosen to represent those typically found in UK lowland grasslands. Each replicate soil block was investigated at each slope angle using a Latin square design to ensure that repeated applications of $\mathrm{P}$ to the soil blocks did not confound determination of the effect of slope on P determination. Owing to space and resources, a maximum of three blocks could be tested simultaneously. Experimental runs were conducted indoors; between runs the soil blocks were kept outdoors. All experimental runs were conducted during June and July 2012, during which weather conditions were generally wet and the temperature was relatively stable, with daily maximum temperatures of 10 to $14^{\circ} \mathrm{C}$. During the experimental runs, deionized water (or nutrient solution) was applied to the soil blocks as simulated overland flow, evenly dispersed across the upslope edge of the block using a sprinkler system. The flow rate onto the block was $30 \mathrm{~L} \mathrm{~h}^{-1}$. This flow rate represented a significant, but not extreme, runoff event, equivalent to $1.5 \mathrm{~mm}$ rain $\mathrm{h}^{-1}$, on an upslope catchment of $40 \mathrm{~m}$ length and $0.5 \mathrm{~m}$ width, assuming complete runoff of all rainfall.

Vegetation on the soil blocks was cut to approximately 2 $\mathrm{cm}$ the day before the application of the nutrient solution (Fig. 2 ). On the same day, the soil was wetted with deionized water (containing $12 \pm 1.2 \mu \mathrm{g} \mathrm{P} \mathrm{L}^{-1}$ ) for approximately $2 \mathrm{~h}$, until the flow rate of the combined surface and subsurface pathways was the same as the application rate, and then allowed to drain for 18 h (Fig. 2). Soil wetting and the drainage were done at the same slope as the subsequent nutrient solution application. Nutrient solution was applied to the blocks for $2 \mathrm{~h}$ and consisted of $17.8 \mathrm{mg} \mathrm{Cl} \mathrm{L}^{-1}$ as potassium chloride as a conservative tracer, $0.7 \mathrm{mg} \mathrm{P} \mathrm{L}^{-1}$ of potassium orthophosphate, $0.3 \mathrm{mg} \mathrm{P} \mathrm{L}^{-1}$ of a labile monoester (glucose-1-phosphate), $0.3 \mathrm{mg} \mathrm{P} \mathrm{L}^{-1}$ of a diester (RNA), and $0.5 \mathrm{mg} \mathrm{P} \mathrm{L}^{-1}$ of IHP, all in deionized water. The TP concentration was $1.8 \mathrm{mg} \mathrm{L}^{-1}$. These concentrations were chosen to be comparable to TP concentrations measured in runoff from real field systems (Kleinman et al., 2002) and to ensure that organic P concentrations in samples would be high enough to measure by the phosphatase hydrolysis method (described below). Immediately after application of the nutrient solution, deionized water was applied for a further $4 \mathrm{~h}$ to flush through $\mathrm{P}$ and $\mathrm{Cl}$, which had been physically, rather than chemically, retained, and the blocks were left to drain at the same slope (Fig. 2).

Water samples for $\mathrm{Cl}, \mathrm{TP}$, and reactive $\mathrm{P}$ (RP) analysis were collected over $7 \mathrm{~h}$ at 15 -min intervals for surface runoff and subsurface flow (Fig. 2). For determination of organic P forms, samples were taken from bulked waters collected between 0 and $2 \mathrm{~h}$ and over 0 to $7 \mathrm{~h}$ (Fig. 2). Discharge was determined by weight, and samples were filtered through $0.45-\mu \mathrm{m}$ cellulose acetate filters (Sterlitech) to obtain the dissolved fraction.

Each soil block was used for three experimental runs. Therefore, there was the potential for

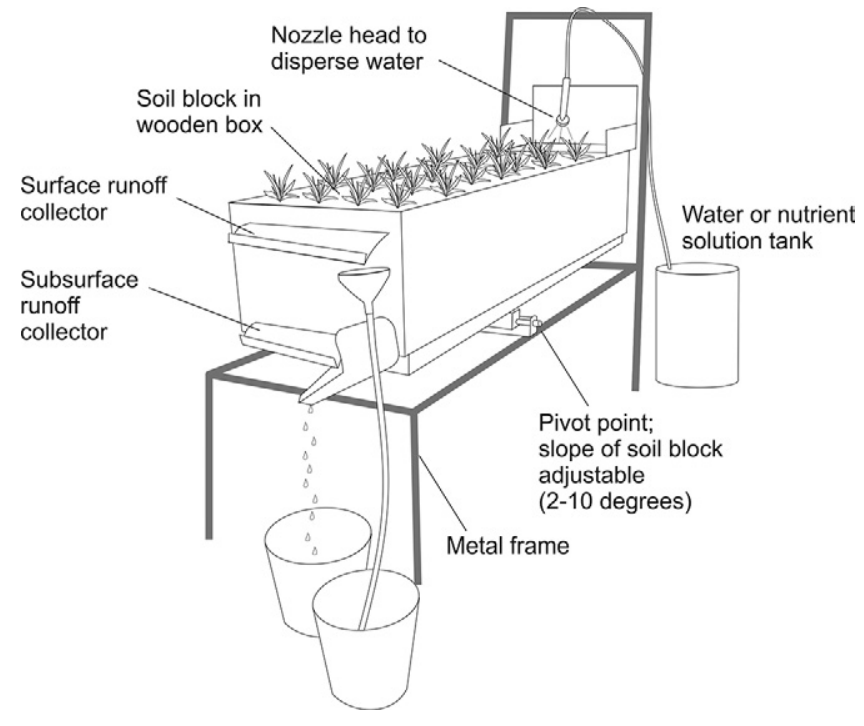

Fig. 1. Schematic demonstrating the main features of the soil blocks and experimental design.

$P$ retained during one experimental run to be mobilized in a subsequent experimental run. To test for this, when the soil blocks were saturated before the nutrient solution application, samples were collected from the surface and subsurface flows for analysis. There was no significant change $(p>0.05)$ in the background concentrations of orthophosphate, organic P, or TP in surface or subsurface flow across the three experimental runs in any soil block.

\section{Sample Analysis}

The analysis of $\mathrm{Cl}, \mathrm{RP}$, and TP was performed using colorimetric analysis on a discrete photometric analyzer (Aquakem 250, Thermo Fisher). Chloride analysis was based on the method by Zall et al. (1956) and RP analysis on the method by Murphy and Riley (1962). Total P analysis was performed after samples were oxidized using an acid persulfate digest (Rowland and Haygarth, 1997). Unreactive P (UP) was calculated as the difference between TP and RP.

Organic P forms were determined using a phosphatase hydrolysis method (Bünemann, 2008). The enzymes used were an alkaline monoesterase from Escherichia coli, a nuclease from Penicillium citrinium, and a phytase from wheat (crude preparation) (all from Sigma Aldrich). Enzymes were dissolved in a $0.5 \mathrm{~mol} \mathrm{~L}^{-1}$ acetate buffer at $\mathrm{pH} 5$, which contained $2 \mathrm{~m} \mathrm{~mol} \mathrm{~L}^{-1}$

Day 1

\begin{tabular}{|c|c|c|c|c|c|c|}
\hline $\begin{array}{c}0-4 \mathrm{~h} \\
\text { vegetation } \\
\text { cut }\end{array}$ & $\begin{array}{c}4-6 \mathrm{~h} \\
\text { deionized } \\
\text { water } \\
\text { application }\end{array}$ & $\begin{array}{c}\text { 6-24 h } \\
\text { drainage } \\
\text { period }\end{array}$ & $\begin{array}{c}0-2 \mathrm{~h} \\
\text { nutrient } \\
\text { application }\end{array}$ & $\begin{array}{c}\text { 2-6h } \\
\text { deionized } \\
\text { water } \\
\text { application }\end{array}$ & $\begin{array}{l}1 \\
1 \\
1 \\
1 \\
1 \\
1 \\
1 \\
1\end{array}$ & $\begin{array}{l}\text { 7-24 h } \\
\text { drainage } \\
\text { period }\end{array}$ \\
\hline & \multicolumn{2}{|c|}{$\begin{array}{l}\stackrel{\text { 4-7 h: } 15 \text { min bulk }}{\text { samples for } \mathrm{Cl}, \mathrm{RP}, \mathrm{TP}} \\
\end{array}$} & \multicolumn{4}{|c|}{ 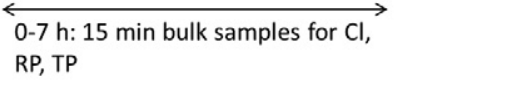 } \\
\hline & \multicolumn{2}{|c|}{ 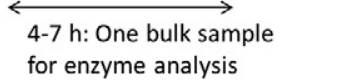 } & \multicolumn{4}{|c|}{$\begin{array}{l}\text { 0-2 } \mathrm{h} \text { and } 2-7 \mathrm{~h}: \text { Two bulk } \\
\text { samples for enzyme analysis }\end{array}$} \\
\hline
\end{tabular}

Fig. 2. Schematic of the experimental procedure and sampling protocol for a single experimental run. This experimental procedure was repeated until every soil block was tested at each of the three slope angles, according to a Latin square design. $\mathrm{RP}$, reactive $\mathrm{P}$; TP, total P. 
magnesium chloride and zinc sulfate. The phytase solution was purified according to Shand and Smith (1997). Organic P forms were determined via incubations of the different phosphatase enzymes with water samples according to Bünemann (2008).

Monoesterase hydrolyzable P (HP) was quantified as the difference between the RP concentration of a sample incubated with monoesterase and the control, nuclease HP was quantified as the difference between the RP concentration of a sample incubated with monoesterase + nuclease and the sample incubated with monoesterase, and phytase HP was quantified as the difference between the RP concentration of a sample incubated with phytase and the sample incubated with monoesterase + nuclease.

Chemical loading to the soil blocks and loads in surface and subsurface flow were calculated as volume of water multiplied by nutrient concentration. Loads were summed to give total loads in water in the 0 - to 2 -h and the 0 - to 7 -h time periods. For each time period, the quantity of each nutrient remaining in the soil was calculated as a percentage of that applied, according to the following equation:

$$
\begin{aligned}
& \text { Retention }(\%)= \\
& \frac{\text { load applied to the block - load released from the block }}{\text { load applied to the block }}
\end{aligned}
$$

The load and percentage retention data are reported for the P forms measured: RP, UP, monoesterase HP, nuclease HP, phytase HP, and TP. For the purposes of the percentage retention calculation, the $\mathrm{P}$ applied is assumed to be the sole component of this (e.g., the glucose-1-phosphate applied to the block is compared with the monoesterase HP released from the block). Furthermore, we define retention as the difference between the amount of nutrient that was applied to the soil block and that measured in surface or subsurface flow. It does not distinguish between physical, chemical, or biological retention or the potential transformation of compounds. These assumptions are considered further in the Discussion section.

\section{Statistical Analysis}

One- and two-way ANOVAs and Fisher's unprotected least significant difference tests were conducted using Genstat (version 14.1.0.5943) to determine significant differences between treatments.

\section{Results}

\section{Hydrology}

Water flow from the clay soil first reached the surface and subsurface collection gutters $21 \pm 2.7$ and $9 \pm 0.7 \mathrm{~min}$ after the start of the nutrient solution application, respectively, and after $34 \pm 4.4$ and $6 \pm 0.3 \mathrm{~min}$, respectively, in the loam soil. On three occasions there was no surface flow from the loam soil blocks (on two occasions at a $10^{\circ}$ slope and on one occasion at a $2^{\circ}$ slope). Over the 7 -h period, a significantly greater $(p<0.001)$ proportion of the total discharge occurred via the subsurface pathway in the loam soil ( $89 \pm 3.8 \%$ of total flow) compared with the clay soil ( $53 \pm 5.4 \%$ of total flow). There was no significant difference $(p$ $>0.05$ ) between the 2,5 , and $10^{\circ}$ slope angles in the proportion of discharge in the surface and subsurface pathways for either soil type. However, the clay soil did demonstrate a trend for the surface pathway to be more dominant at the $10^{\circ}$ slope than at lower slope angles, with surface flow comprising $42 \pm 12 \%$ of the total discharge at $2^{\circ}, 45 \pm 11 \%$ at $5^{\circ}$, and $55 \pm 7 \%$ at $10^{\circ}$. A total of $94.9 \pm 1.22 \%$ of the water applied to the clay soil was recovered in surface and subsurface flow over the 7 -h period, and $96.4 \pm 0.90 \%$ from the loam soil was recovered.

\section{Water Chemistry}

Figure 3 illustrates the $\mathrm{Cl}, \mathrm{RP}, \mathrm{TP}$, and UP concentrations determined in samples collected over 15-min periods during the periods of nutrient solution application, water application, and drainage. For both soil types and flow pathways, there were generally increases in nutrient concentrations during the application of the nutrient solution $(0-2 \mathrm{~h})$. Subsequently, concentrations decreased during the deionized water application (2-7 h) until they reached a steady state. Generally, concentrations of UP and RP reached a steady state $30 \mathrm{~min}$ and $2 \mathrm{~h}$, respectively, after the start of water application. Typically, mean $\mathrm{Cl}, \mathrm{RP}$, and UP concentrations were greater in surface flow than in subsurface flow from both soil types between 0 and $2 \mathrm{~h}$, over the whole 7-h period, and at steady state, but differences were not always significant. Similarly, mean Cl, RP, and UP concentrations were generally greater from the loam soil than from the clay soil in both pathways at all time periods, but differences were not always significant.

Differences between the maximum concentration of RP in surface runoff (1.75-2 $\mathrm{h}$ after start of nutrient application) and the concentration of RP applied $\left(0.7 \pm 0.02 \mathrm{mg} \mathrm{L}^{-1}\right.$ on the clay soils and $0.7 \pm 0.01 \mathrm{mg} \mathrm{L}^{-1}$ on the loam soils) were not significant $(p>0.05)$. However, subsurface concentrations were significantly reduced $(p<0.05)$ to $0.4 \pm 0.05 \mathrm{mg} \mathrm{L}^{-1}$ from the clay soil and $0.5 \pm 0.02 \mathrm{mg} \mathrm{L}^{-1}$ from the loam soil. Similarly, maximum $\mathrm{Cl}$ concentrations in surface runoff were not significantly different $(p$ $>0.05$ ) from the applied nutrient solution but were significantly reduced $(p<0.05)$ in subsurface flow. In contrast, the maximum UP concentrations were significantly $(p<0.05)$ smaller than in the applied nutrient solution in both surface and subsurface flow.

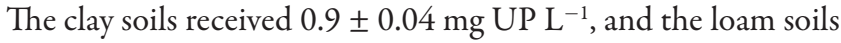
received $1.0 \pm 0.09 \mathrm{mg} \mathrm{UP} \mathrm{L}^{-1}$. Maximum concentrations of UP were $0.6 \pm 0.15 \mathrm{mg} \mathrm{L}^{-1}$ in surface runoff and $0.3 \pm 0.03 \mathrm{mg} \mathrm{L}^{-1}$ in subsurface flow in the clay soil and $0.9 \pm 0.36$ in surface runoff and $0.3 \pm 0.04 \mathrm{mg} \mathrm{L}^{-1}$ in subsurface flow in the loam soil.

Slope

There was no significant effect $(p>0.05)$ of slope on the concentration of nutrients, the percentage retention of nutrients, or the load of nutrients retained for either soil type or for either time period $(0-2 \mathrm{~h}$ or the over the 7 -h period) (Table 2$)$. However, the clay soil did demonstrate a trend for the percentage retention of nutrients to be the smallest at the $10^{\circ}$ slope at both time points (Table 2). For example, between 0 and $2 \mathrm{~h}$, TP retention was $79 \pm 3.8 \%, 77 \pm 8.5 \%$, and $69 \pm 9.7 \%$ at the 2 , 5 , and $10^{\circ}$ slope angles, respectively (Table 2 ). Over $7 \mathrm{~h}, \mathrm{TP}$ retention was $39 \pm 7.3 \%, 53 \pm 15.6 \%$, and $35 \pm 6.0 \%$ at the 2,5 , and $10^{\circ}$ slope angles, respectively. Due to the lack of a significant effect of slope, all subsequent data are a mean of the three slope angles $(n=9)$. 

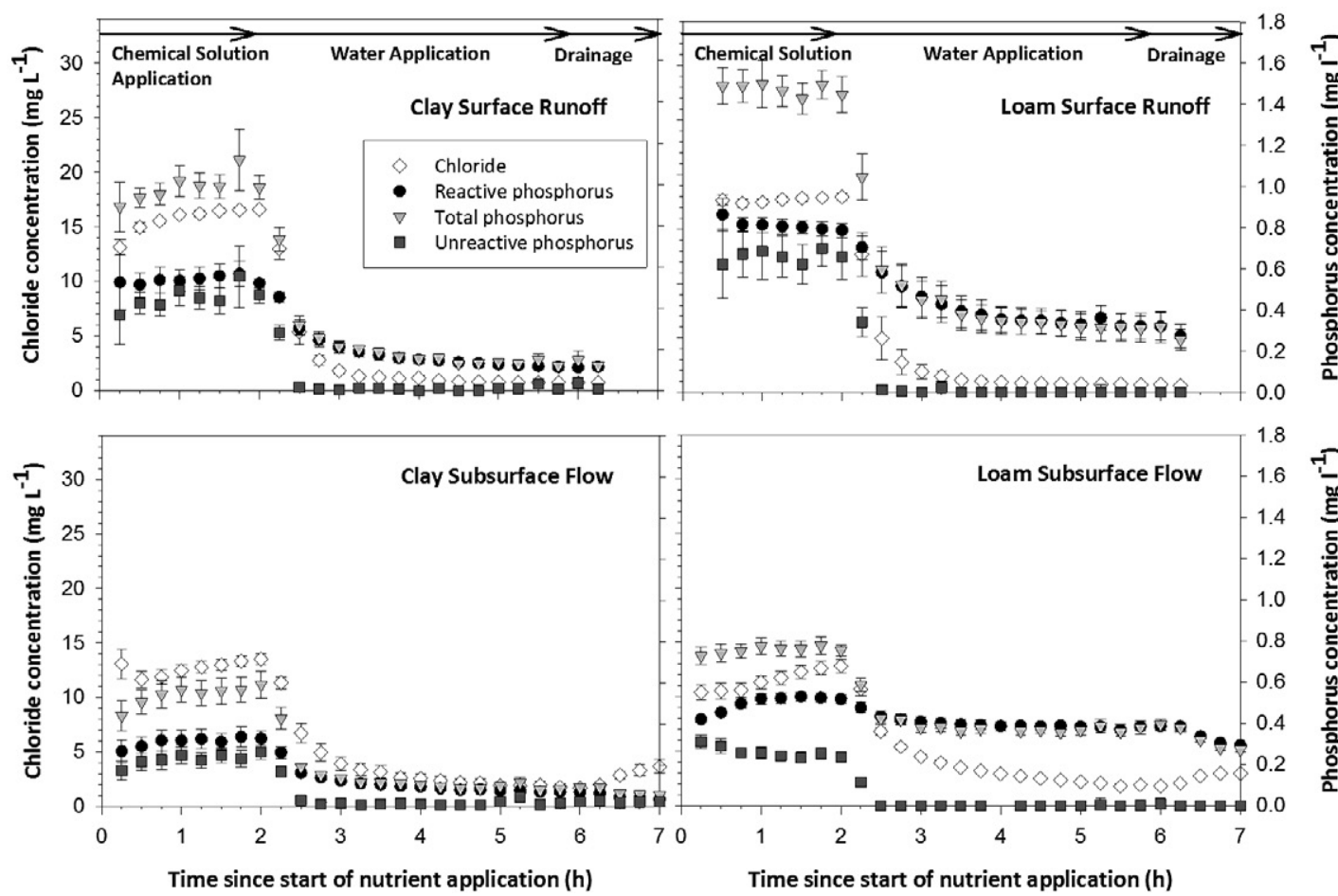

Fig. 3. Scatterplot showing the reactive $P$, total $P$, unreactive $P$, and chloride concentrations in the surface and subsurface flow of the clay and loam soils ( $n=9$, with the exception of loam surface flow, where $n=6$ ). Error bars indicate 1 SE.

\section{Soil Type}

Between 0 and $2 \mathrm{~h}$, there was no significant difference $(p>$ $0.05)$ between the clay and the loam soils for the percentage retention of applied $\mathrm{Cl}(57 \pm 7.3$ and $55 \pm 5.2 \%$, respectively). At this time point, $\mathrm{Cl}$ retention is likely to be partly due to physical retention within the pores between soil particles, but mostly this retention occurred because $\mathrm{Cl}$ applied to the surface of the soil block had not had time to reach the surface and subsurface drains. Between 0 and $2 \mathrm{~h}$, the clay soil retained a significantly greater $(p<0.05)$ proportion of the applied RP and UP than the loam soil; the clay and loam soils retained $69 \pm 5.0 \%$ and $50 \pm$ $7.4 \%$ of applied RP, respectively, and $80 \pm 4.4 \%$ and $75 \pm 5.1 \%$ of UP, respectively (Table 3 ).

Over the 7-h period, the loam soil retained a greater $(p<$ $0.05)$ percentage of the $\mathrm{Cl}$ in the applied solution than the clay soil ( $15 \pm 2.3 \%$ in loam and $5 \pm 8.4 \%$ in clay) and of UP (74 \pm $4.3 \%$ in loam and $60 \pm 7.0 \%$ in clay). In contrast, the percentage retention of RP was greater $(p<0.05)$ from the clay soil than from the loam soil at $21 \pm 7.5 \%$ and $-61 \pm 6.7 \%$, respectively. The negative value for the loam soil is due to the total load of $P$ in discharge waters being greater than the load applied. The percentage retention of TP was also greater $(p<0.05)$ in the clay soil at $42 \pm 5.9 \%$, compared with $17 \pm 5.7 \%$ in the loam soil.

At 0 to $2 \mathrm{~h}$ and over $7 \mathrm{~h}$, there were no significant differences $(p>0.05)$ between the loam and clay soils in the percentage retention of any of the organic $\mathrm{P}$ forms, as analyzed using phosphatase hydrolysis (Table 4). However, the trend was for the percentage retention of compounds to be greater in the clay soil.

\section{Comparative Retention of P Forms}

The percentage retention and load retention of UP were both significantly $(p<0.05)$ greater than for RP in both soil types and at 0 to $2 \mathrm{~h}$ and over the whole 7 -h period (Table 3 ). In the 0 - to 2-h samples, the clay soil retained $80 \%$ ( $39 \mathrm{mg}$ ) of applied UP and $69 \%$ (30 mg) of the RP, whereas the loam soil retained $75 \%$ ( $47 \mathrm{mg}$ ) of UP and $50 \%$ ( $23 \mathrm{mg}$ ) of RP. Over the 7-h period, the difference between nutrients was greater, with $60 \%(29 \mathrm{mg}$ )

Table 2. Retention of chloride, reactive $\mathrm{P}$, total $\mathrm{P}$, and unreactive $\mathrm{P}$ as a percentage of that applied for 2,5 , and $10^{\circ}$ slope angles on the clay and loam soils between 0 and $2 \mathrm{~h}$ (nutrient solution application) and between 0 and $7 \mathrm{~h}$ (nutrient solution application followed by water application)

\begin{tabular}{|c|c|c|c|c|c|c|c|}
\hline \multirow{2}{*}{ Time point } & \multirow{2}{*}{ Nutrient† } & \multicolumn{3}{|c|}{ Clay } & \multicolumn{3}{|c|}{ Loam } \\
\hline & & $2^{\circ}$ slope & $5^{\circ}$ slope & $10^{\circ}$ slope & $2^{\circ}$ slope & $5^{\circ}$ slope & $10^{\circ}$ slope \\
\hline $0-2 \mathrm{~h}$ & $\mathrm{Cl}$ & $67 \pm 2.3 \neq$ & $59 \pm 13.5$ & $46 \pm 18.3$ & $46 \pm 2.2$ & $69 \pm 15.3$ & $54 \pm 1.8$ \\
\hline $0-2 \mathrm{~h}$ & $\mathrm{RP}$ & $76 \pm 3.2$ & $68 \pm 10.4$ & $63 \pm 11.5$ & $40 \pm 4.2$ & $68 \pm 24.2$ & $46 \pm 5.7$ \\
\hline $0-2 \mathrm{~h}$ & TP & $79 \pm 3.8$ & $77 \pm 8.5$ & $69 \pm 9.7$ & $57 \pm 6.5$ & $79 \pm 16.5$ & $61 \pm 4.4$ \\
\hline $0-2 \mathrm{~h}$ & UP & $82 \pm 4.4$ & $85 \pm 9.3$ & $73 \pm 9.6$ & $68 \pm 8.3$ & $86 \pm 10.8$ & $73 \pm 5.2$ \\
\hline $0-7 \mathrm{~h}$ & $\mathrm{Cl}$ & $7 \pm 6.1$ & $22 \pm 20.6$ & $-14 \pm 7.3$ & $11 \pm 2.4$ & $13 \pm 2.8$ & $20 \pm 5.9$ \\
\hline $0-7 \mathrm{~h}$ & $\mathrm{RP}$ & $22 \pm 3.4$ & $28 \pm 23.9$ & $13 \pm 6.6$ & $-64 \pm 17.3$ & $-56 \pm 5.0$ & $-59 \pm 0.8$ \\
\hline $0-7 \mathrm{~h}$ & TP & $39 \pm 7.3$ & $53 \pm 15.6$ & $35 \pm 6.0$ & $13 \pm 13.7$ & $26 \pm 5.0$ & $15 \pm 0.3$ \\
\hline $0-7 \mathrm{~h}$ & UP & $53 \pm 9.3$ & $76 \pm 9.4$ & $51 \pm 14.6$ & $69 \pm 7.9$ & $78 \pm 5.5$ & $78 \pm 10.6$ \\
\hline
\end{tabular}

† RP, reactive $P$; TP, total $P$; UP, unreactive $P$.

‡ Values are percentage $\pm 1 \mathrm{SE}$.

Journal of Environmental Quality 
of the UP and $21 \%$ ( $8 \mathrm{mg}$ ) of RP being retained in the clay soil and $74 \%$ ( $48 \mathrm{mg}$ ) of the UP and $-61 \%$ (28 $\mathrm{mg}$ net loss) of RP in the loam soil.

Significantly more $(p<0.05)$ of the UP was retained than $\mathrm{Cl}$ in both soil types and for both time periods; over $7 \mathrm{~h}, 5$ and $15 \%$ of applied $\mathrm{Cl}$ was retained in the clay and loam soils, respectively, and 60 and $74 \%$, respectively, of the UP was retained (Table 3). Between 0 and $2 \mathrm{~h}$ in the loam soil and over both time periods in the clay soil, there was no significant difference between RP and $\mathrm{Cl}$ retention, although the percentage retention of $\mathrm{RP}$ tended to be slightly greater (Table 3 ). Conversely, in the loam soil over $7 \mathrm{~h}$, $\mathrm{Cl}$ was significantly better retained than $\mathrm{RP}(p<0.05)$.

The percentage retention and the load retention of $P$ was significantly affected $(p<0.001)$ by the form of $\mathrm{P}$ at 0 to $2 \mathrm{~h}$ and over $7 \mathrm{~h}$ and in both soils. In general, the percentage retention of $\mathrm{P}$ compounds in both soil types and at both time points was in the order phytase $\mathrm{HP}>$ monoesterase $\mathrm{HP}>$ diesterase $\mathrm{HP}>\mathrm{RP}$ (Table 4). For example, in the loam soil over $7 \mathrm{~h}$, the percentage retention of phytase HP, monoesterase HP, diesterase HP, and $\mathrm{RP}$ was $63 \pm 9.1 \%(26.7 \pm 5.37 \mathrm{mg}), 49 \pm 9.3 \%(12.3 \pm 3.31$ $\mathrm{mg}), 34 \pm 6.4 \%$ (6.8 $\pm 1.54 \mathrm{mg})$, and $-70 \pm 1.8 \%(-31.8 \pm 5.35$ $\mathrm{mg}$ ) of the applied $\mathrm{P}$, respectively (Table 4 ).

\section{Discussion}

\section{Slope}

This study found no significant effect of slope on the retention of $\mathrm{P}$ at slopes of between 2 and $10^{\circ}$. Although previous research has indicated that an increasing slope decreases $\mathrm{P}$ retention, the focus is usually on particulate forms of P (e.g., Dillaha et al., 1989); hence, few data on dissolved forms are available for comparison. However, it should be considered that the velocity of the water applied to the soil blocks was independent of the slope at which they were set, whereas the velocity of surface water flowing on to a buffer strip in a field situation is likely to increase with slope. The water was applied to the blocks at only one rate, equivalent to prolonged low-intensity rainfall, and may not be representative of higher-intensity rainfall. Furthermore, the soil blocks were wetted before nutrient application but then received no further water apart from the runoff water. These factors may also explain why there was not a stronger trend of surface flow increasing as a proportion of total flow with an increase in slope. In contrast, buffer strips in a field situation would be at antecedent conditions before receiving both rainfall and runoff. It is difficult to predict whether these factors may have masked

Table 3. Loading of chloride, reactive $P$, total $P$, and unreactive $P$ applied to the clay and loam soils and the retention of those nutrients between 0 and $2 \mathrm{~h}$ (nutrient solution application) and between 0 and $7 \mathrm{~h}$ (nutrient solution application followed by water application).

\begin{tabular}{|c|c|c|c|c|c|c|c|}
\hline \multirow{2}{*}{ Time point } & \multirow{2}{*}{ Nutrient $†$} & \multicolumn{2}{|c|}{ Nutrient applied } & \multicolumn{2}{|c|}{ Retention } & \multicolumn{2}{|c|}{ Retention } \\
\hline & & Clay & Loam & Clay & Loam & Clay & Loam \\
\hline & & \multicolumn{4}{|c|}{$\longrightarrow$ total load $(\mathrm{mg}) \longrightarrow$} & \multicolumn{2}{|c|}{ — \% of that applied — } \\
\hline $0-2 \mathrm{~h}$ & $\mathrm{Cl}$ & $987 \pm 43.7 \neq$ & $1230 \pm 67.0$ & $560 \pm 71.7$ & $656 \pm 52.8$ & $57 \pm 7.3 a \S x \uparrow$ & $55 \pm 5.2 \mathrm{ax}$ \\
\hline $0-2 \mathrm{~h}$ & $\mathrm{RP}$ & $43 \pm 3.1$ & $48 \pm 2.3$ & $30 \pm 2.9$ & $23 \pm 3.0$ & $69 \pm 5.0 \mathrm{ax}$ & $50 \pm 7.4 b x$ \\
\hline $0-2 \mathrm{~h}$ & TP & $93 \pm 4.1$ & $114 \pm 7.1$ & $69 \pm 3.7$ & $70 \pm 8.7$ & $75 \pm 4.2$ & $64 \pm 5.9$ \\
\hline $0-2 \mathrm{~h}$ & UP & $50 \pm 2.2$ & $66 \pm 5.7$ & $39 \pm 1.7$ & $47 \pm 5.4$ & $80 \pm 4.4 a y$ & $75 \pm 5.1 \mathrm{bz}$ \\
\hline $0-7 \mathrm{~h}$ & $\mathrm{Cl}$ & \multicolumn{2}{|c|}{ as $0-2 \mathrm{~h}$} & $28 \pm 70.6$ & $181 \pm 42.2$ & $5 \pm 8.4 a x$ & $15 \pm 2.3 b x$ \\
\hline $0-7 \mathrm{~h}$ & $\mathrm{RP}$ & & & $8 \pm 2.6$ & $-28 \pm 3.4$ & $21 \pm 7.5 \mathrm{ax}$ & $-61 \pm 6.7 b y$ \\
\hline $0-7 \mathrm{~h}$ & $\mathrm{TP}$ & & & $38 \pm 3.5$ & $20 \pm 7.2$ & $42 \pm 5.9$ & $17 \pm 5.7$ \\
\hline $0-7 \mathrm{~h}$ & UP & & & $29 \pm 2.8$ & $48 \pm 5.4$ & $60 \pm 7.0$ ay & $74 \pm 4.3 b z$ \\
\hline
\end{tabular}

† RP, reactive $P$; TP, total $P$; UP, unreactive $P$.

$\neq$ Values are total load \pm SE or percentage \pm SE as noted.

$\S$ Different letters ( $\mathrm{a}$ or $\mathrm{b}$ ) indicate significant differences between the percentage retention of $\mathrm{Cl}$, RP, and UP in the clay and loam soils within a nutrient type and time period.

I Different letters $(x, y$, or $z$ ) indicate significant differences between the percentage retention of $\mathrm{Cl}$, $\mathrm{RP}$, and UP, within a soil type and time period.

Table 4. Loading of reactive $\mathrm{P}$ (applied as orthophosphate), monoesterase hydrolyzable $\mathrm{P}$ (applied as glucose-1-phosphate), diesterase hydrolyzable $\mathrm{P}$ (applied as RNA), and phytase hydrolyzable P (applied as inositol hexakisphosphate) applied to the clay and loam soils and the retention of those nutrients between 0 and $2 \mathrm{~h}$ (nutrient solution application) and between 0 and $7 \mathrm{~h}$ (nutrient solution application followed by water application).

\begin{tabular}{|c|c|c|c|c|c|c|c|}
\hline \multirow{2}{*}{ Time point } & \multirow{2}{*}{ Nutrient $†$} & \multicolumn{2}{|c|}{ Nutrient applied } & \multicolumn{2}{|c|}{ Retention } & \multicolumn{2}{|c|}{ Retention } \\
\hline & & Clay & Loam & Clay & Loam & Clay & Loam \\
\hline & & & to & $(\mathrm{mg})$ & - & $-\%$ of $t$ & oplied - \\
\hline $0-2 \mathrm{~h}$ & $\mathrm{RP}$ & $40 \pm 2.0 \neq$ & $47 \pm 3.4$ & $19.3 \pm 1.34 \mathrm{a} \S$ & $19.1 \pm 3.20 \mathrm{a}$ & $54 \pm 5.0 \mathrm{a}$ & $39 \pm 4.4 a$ \\
\hline $0-2 \mathrm{~h}$ & monoesterase HP & $17 \pm 1.6$ & $21 \pm 3.8$ & $11.0 \pm 0.89 b$ & $14.2 \pm 3.26 \mathrm{ab}$ & $72 \pm 3.1 b$ & $61 \pm 6.2 c$ \\
\hline $0-2 \mathrm{~h}$ & diesterase HP & $20 \pm 1.2$ & $15 \pm 2.2$ & $9.4 \pm 0.72 b$ & $9.7 \pm 1.44 b$ & $52 \pm 5.2 a$ & $50 \pm 4.8 b$ \\
\hline $0-2 \mathrm{~h}$ & phytase HP & $31 \pm 4.5$ & $42 \pm 4.3$ & $25.0 \pm 4.24 a$ & $35.7 \pm 5.25 c$ & $84 \pm 4.3 b$ & $84 \pm 5.7 b c$ \\
\hline $0-7 \mathrm{~h}$ & $\mathrm{RP}$ & as $0-2 \mathrm{~h}$ & & $5.1 \pm 1.89 a$ & $-31.8 \pm 5.35 a$ & $15 \pm 6.0 \mathrm{a}$ & $-70 \pm 11.8 a$ \\
\hline $0-7 \mathrm{~h}$ & monoesterase HP & & & $10.2 \pm 0.89 a$ & $12.3 \pm 3.31 \mathrm{~b}$ & $66 \pm 3.1 b c$ & $49 \pm 9.3 b$ \\
\hline $0-7 \mathrm{~h}$ & diesterase HP & & & $8.1 \pm 0.80 a$ & $6.8 \pm 1.54 b$ & $45 \pm 5.5 b$ & $34 \pm 6.4 b$ \\
\hline $0-7 \mathrm{~h}$ & phytase HP & & & $21.0 \pm 4.8 \mathrm{~b}$ & $26.7 \pm 5.37 c$ & $63 \pm 11.2 c$ & $63 \pm 9.1 b$ \\
\hline
\end{tabular}

†RP, reactive $P$; TP, total $P$; UP, unreactive $P$.

$\neq$ Values are total load \pm SE or percentage \pm SE as noted.

$\S$ Different letters indicate significant differences in values within a soil type and time period. 
the effect of slope on P retention without further tests with closer replication of field conditions.

\section{Soil Type}

The differing physical properties of the loam and clay soils are reflected in the hydrology of the soil blocks. The greater proportion of total flow occurring via the subsurface pathway in the loam soil indicates the greater permeability of this soil relative to the clay soil. The relative importance of the surface and subsurface pathways in the two soils is also reflected in the time it takes water to reach the gutters. For example, the greater permeability of the loam soil means that water movement via the piston effect in the subsurface pathway occurs earlier than in the clay soil. Conversely, in the clay soil, more water has remained at the surface to generate surface runoff.

The clay and loam soils received different loads of $\mathrm{P}$ (Table 3) due to variability in the water application rate despite attempts to calibrate the sprinklers. However, the additional P applied to the loam soil did not cause increased leaching from successive runs, as shown in samples taken during the wetting-up period before nutrient application. Therefore, for comparison of the two soil types for the retention of dissolved $\mathrm{P}$, the percentage retention data are considered to be more accurate than the load data.

Reactive $\mathrm{P}$ was greater in the clay soil than in the loam soil, but the results for UP retention were more equivocal. The percentage retention of UP was lower $(p<0.05)$ in the loam soil than the clay soil between 0 and $2 \mathrm{~h}$ but was greater $(p<$ 0.05 ) over $7 \mathrm{~h}$, and the results of the phosphatase hydrolysis found the percentage retention of the individual organic $\mathrm{P}$ compounds to be greater $(p>0.05)$ in the clay soil at both time points. The greater sorption of $\mathrm{P}$ to clay soils is often attributed to the higher surface area to volume ratio of the finer-textured clay soil compared with sand and silt soils (Glæsner et al., 2011b; Syversen and Borch, 2005; Ullah et al., 1983) and to the greater number of $\mathrm{Al}$ and $\mathrm{Fe}$ oxides to which $\mathrm{P}$ sorbs (Brady and Weil, 2008). The greater tendency for water to move via overland flow paths in clay soils, as seen in this study, reduces the soil-water contact and thus reduces opportunities for retention. This study found $\mathrm{P}$ retention to generally be higher in a clay soil than in a loam soil, indicating that the chemistry of a soil may be more important than the hydrological pathways for the physical and chemical retention of dissolved $\mathrm{P}$. This is contrary to the findings of Akhtar et al. (2003). However, the initial P content of the loam soil was higher than in the clay soil (Table 1), which may have reduced $\mathrm{P}$ sorption and/or increased $\mathrm{P}$ desorption from the loam soil relative to the clay soil (Hahn et al., 2012). Furthermore, it is unknown whether our results would have differed at a higher water application rate.

\section{Comparative Retention of P Forms}

The results demonstrated that the percentage retention of UP was significantly greater than RP retention in both the clay and loam soils and at 0 to $2 \mathrm{~h}$ and over the whole 7 -h period. Furthermore, RP was more poorly retained than any individual organic $\mathrm{P}$ compound. These results indicate that only a small proportion of UP was retained through physical processes (retention of $\mathrm{P}$ in pores between soil particles, as opposed to chemical or biological retention or turnover) but that this could explain the retention of all of the RP.
These results contradict studies that indicate that dissolved organic P is more mobile than orthophosphate (Murphy, 2007; Toor et al., 2005). Furthermore, noncompetitive adsorption isotherms generally indicate orthophosphate adsorption to be similar to IHP adsorption and greater than the adsorption of labile monoester P and diester P (Anderson and Magdoff, 2005; Guan et al., 2005; Shang et al., 1990). The difference in orthophosphate retention between our results and previous studies may partially be due to the fact that in our study multiple P compounds were added to the soil, as opposed to single compounds. There is evidence that labile monoesters, diesters, and orthophosphate compete for the same sorption sites (Berg and Joern, 2006; Guan et al., 2005) and that the addition of organic $\mathrm{P}$ compounds to soil can displace soil orthophosphate (Berg and Joern, 2006; Bowman et al., 1967). Furthermore, the proportion of the TP in the applied solution that was orthophosphate (40\%) was within the range measured in surface and subsurface flow from land in the absence of fertilizer (Preedy et al., 2001). Therefore, any competition between orthophosphate and organic $\mathrm{P}$ compounds would be similar to that found in real soil systems.

Our results may also differ from those of other studies due to the use of intact soil blocks that retained soil structure. Current knowledge on the relative retention of P compounds results largely from sorption studies in which the soil has been shaken with compounds in solution, providing maximal time for retention and a greater surface area for sorption due to disruption of aggregates. Furthermore, we studied only one compound from each of the labile monoester, diester, and inositol P groups, and, because chemical structure can vary widely even within a group (Turner et al., 2005), the compounds studied here may not be representative of other organic P compounds. However, the relative retention of the organic compounds of phytase HP (IHP) > monoesterase HP (glucose-1-phosphate) > diesterase HP (RNA) was as predicted from the results of studies using different compounds from the labile monoester and diester groups (Anderson and Magdoff, 2005; Guan et al., 2005; Shang et al., 1990), suggesting that the choice of compounds was unlikely to be a factor.

The wetting of the soil blocks the day before conducting experimental runs may have affected leaching of dissolved RP (likely to be mostly orthophosphate). This has previously been reported to be greater than the leaching of dissolved UP under saturated soil conditions, whereas the opposite is true under unsaturated conditions (Jensen et al., 2000). The difference in P transport was due to RP, but not UP, transport being coupled with preferential pathways present only at high soil high water contents (Jensen et al., 2000).

The hydrolysis of organic P compounds during soil column experiments has previously been identified (Anderson and Magdoff, 2005). However, hydrolysis processes are difficult to separate from the physical displacement of native soil P resulting from addition of organic $P$.

Literature reporting of the residence times of $\mathrm{P}$ compounds in soils is scarce but indicates that labile monoesters are the most readily hydrolyzed form of organic P (Darch et al., 2014). The complete hydrolysis of a labile monoester (glycerophosphate) has been reported within $3 \mathrm{~d}$, compared with $18 \mathrm{~d}$ for RNA (Bowman and Cole, 1978) and even longer for IHP (Hayes et al., 1999). Because retention was calculated as the nonemergence

Journal of Environmental Quality 
of $\mathrm{P}$ in surface or subsurface flow, the observed pattern of greater retention of UP compared with RP could be partially explained by hydrolysis of UP.

The physical retention of $\mathrm{P}$ in micro- or macropores was assumed to be equal to the retention of the conservative $\mathrm{Cl}$ tracer because only a small proportion (5-15\%) of Cl was retained over $7 \mathrm{~h}$. Biological retention of $\mathrm{P}$, via uptake and incorporation into cells, is more difficult to quantify. However, on the timescale of this experiment, orthophosphate is likely to have been preferentially taken up over organic P (Condron et al., 2005), and this would have resulted in the appearance of greater RP retention. Because this form of $\mathrm{P}$ was the most poorly retained of the $\mathrm{P}$ compounds, it is unlikely that biological retention had a significant role in explaining our results.

In calculating the percentage retention of compounds, we assumed that all RP measured in the samples was derived from the orthophosphate applied in the nutrient solution, as opposed to the native soil orthophosphate or organic $\mathrm{P}$ hydrolyzed during the molybdate blue detection method (Haygarth and Sharpley, 2000). Likewise, it was assumed that the monoesterase HP, nuclease HP, and phytase HP equated to the applied glucose-1phosphate, RNA, and IHP, respectively, rather than native soil organic P compounds. However, both RP and UP were present in samples taken before the nutrient solution application, indicating that some loss of native soil $\mathrm{P}$ was occurring. The majority of $\mathrm{P}$ in these samples was RP $(78-100 \%$ for both the pathways and soil types), and the majority of the organic $\mathrm{P}$ was phytase HP (69-100\%). With the exception of IHP, P compounds tend to compete for the same binding sites (Berg and Joern, 2006). Therefore, the addition of the nutrient solution to the soil may have resulted in displacement of native soil P (Guan et al., 2005), which, based on analysis of the samples taken during the wetting-up phase, was most likely orthophosphate. The quantity of displaced $\mathrm{P}$ is impossible to estimate because the samples taken during the wetting-up phase had generally greater $\mathrm{P}$ concentrations than the water samples collected during steadystate flow. However, if a large proportion of the RP measured during the experimental runs was from native soil $\mathrm{P}$ rather than from the added orthophosphate, this may explain why the relative retention of orthophosphate was small in the soils studied here, compared with previous studies. Further studies using radio-isotopes of $\mathrm{P}$ may aid our understanding.

It is likely that the relative retention of $\mathrm{P}$ compounds is a complex interaction of the reasons discussed above and highlights our lack of knowledge both in laboratory-scale studies and in real soil systems.

\section{Effectiveness of a 2-m Buffer Strip}

In our study, a $2-\mathrm{m}$ soil block was used to experimentally simulate a 2 - $m$ buffer strip because this is the minimum width for which farmers in the United Kingdom can receive grants under agri-environment schemes, such as the Entry Level Stewardship (Natural England and Defra, 2013). Reactive P retention (over 7 h) was $21 \%$ in the clay soil and $-61 \%$ in the loam soil, indicating net leaching of native soil $P$ from the latter soil. These values sit within the wide range of values measured for the retention of dissolved RP within buffer strips of between 2 and $26 \mathrm{~m}$, which range from -71 to $95 \%$ retention, with a median value of $65 \%$ (Hoffmann et al., 2009).
In their review, Dorioz et al. (2006) concluded that a buffer strip of between 8 and $15 \mathrm{~m}$ was required to retain at least $60 \%$ of the dissolved P entering it. Although our results do not contradict this statement, we found that a 2 -m buffer strip, of the soil types tested here, can be effective at reducing loads of UP being transported to watercourses ( $>50 \%)$, even after discounting potential physical retention of $\mathrm{P}$ in soil pores. On the other hand, the leaching of native soil $\mathrm{P}$ observed in the loam soil indicates that a wider buffer strip could potentially exacerbate orthophosphate loss. However, the application rate of the nutrient solution and water as overland flow was equivalent to low-intensity rainfall events on saturated land. Under higherintensity rainfall, the retention and mobilization of $\mathrm{P}$ and the hydrology of the soil may differ, and the effectiveness of the 2-m buffer strip may be different.

Although the load of $\mathrm{P}$ being transported to water is important from an agronomic viewpoint, it is the $\mathrm{P}$ concentration that is key in assessing the eutrophication risk to a watercourse (Correll, 1998). Although the experimental application of a nutrient solution followed by a water wash may not replicate real field situations, the $\mathrm{P}$ concentrations that we applied were within the range of concentrations seen in published data (e.g., Hahn et al., 2012; Kleinman et al., 2002). Therefore, this study finds that, although a 2-m buffer strip can reduce UP loads, it may not be sufficient to reduce concentrations of dissolved RP to within the limits acceptable $\left(<0.12 \mathrm{mg} \mathrm{P} \mathrm{L}^{-1}\right)$ under the Water Framework Directive.

\section{Conclusions}

It was found that (i) slope does not have a significant effect on either dissolved UP or RP retention; (ii) the retention of orthophosphate, glucose-1-phosphate, RNA, and IHP are generally greater in the clay soil than the loam soil; and (iii) organic $P$ retention in both soil types is greater $(>60 \%$ of applied P) than orthophosphate retention $(<21 \%)$. The findings indicate that slope is less important for $P$ retention than soil type within the slopes tested $\left(2-10^{\circ}\right)$ and at the water application rate and scale studied. In summary, our experiment has shown that, for the soils tested, 2-m-wide buffer strips can be effective at retaining dissolved UP but are less effective at retaining the more bioavailable dissolved RP. This has implications for water quality because the European Water Framework Directive only considers RP concentration, rather than TP. However, the leaching of native soil RP observed in the loam soil means that increasing the buffer strip width may not offer a solution. Furthermore, the UP retained in the buffer strip may be biologically cycled and remobilized as RP and hence has the potential to contribute to future water quality problems.

\section{Acknowledgments}

The authors thank Steve Granger, Nanding, Gordon Fishleigh, Andy Bartram, and Colin Lethbridge for assistance with the collection of soil blocks and the design and construction of materials used during the experiment; Dr. Dan Dhanoa for statistical advice; and Andrew Bristow, Denise Headon, and Liz Dixon for laboratory advice and analysis. This work was funded by the UK Department for Environment, Food and Rural Affairs (Defra) on project number WQ0126, Modular approaches to the control of diffuse agricultural pollution: buffer zones, bioreactors, ditches and ponds. Rothamsted Research receives funding from the Biotechnology and Biological Sciences Research Council (BBSRC). 


\section{References}

Akhtar, M.S., B.K. Richards, P.A. Medrano, M. DeGroot, and T.S. Steenhuis. 2003. Dissolved phosphorus from undisturbed soil cores: Related to adsorption strength, flow rate, or soil structure? Soil Sci. Soc. Am. J. 67(2):458-470. doi:10.2136/sssaj2003.4580

Anderson, B.H., and F.R. Magdoff. 2005. Relative movement and soil fixation of soluble organic and inorganic phosphorus. J. Environ. Qual. 34:2228-2233. doi: $10.2134 /$ jeq2005.0025

Berg, A.S., and B.C. Joern. 2006. Sorption dynamics of organic and inorganic phosphorus compounds in soil. J. Environ. Qual. 35:1855-1862. doi:10.2134/ jeq2005.0420

Blackwell, M.A., A. Carswell, and R. Bol. 2013. Variations in concentrations of N and $\mathrm{P}$ forms in leachates from dried soils rewetted at different rates. Biol. Fertil. Soils 49(1):79-87. doi:10.1007/s00374-012-0700-7

Bowman, B.T., R.L. Thomas, and D.E. Elrick. 1967. Movement of phytic acid in soil cores. Soil Sci. Soc. Am. Proc. 31(4):477-481. doi:10.2136/ sssaj1967.03615995003100040018x

Bowman, R.A., and C.V. Cole. 1978. Transformations of organic phosphorus substrates in soils as evaluated by NaHCO3 extraction. Soil Sci. 125(1):49-54. doi:10.1097/00010694-197801000-00008

Brady, N.C., and R.R. Weil. 2008. The nature and properties of soils. Pearson Education, Cranbury, NJ

Bünemann, E.K. 2008. Enzyme additions as a tool to assess the potential bioavailability of organically bound nutrients. Soil Biol. Biochem. 40(9):2116-2129. doi:10.1016/j.soilbio.2008.03.001

Condron, L.M., B.L. Turner, and B.J. Cade-Menun. 2005. Chemistry and dynamics of soil organic phosphorus. In: J.T. Sims and A.N. Sharpley, editors, Phosphorus: Agriculture and the environment. ASA-CSA-SSSA, Madison, WI. p. 87-121.

Correll, D.L. 1998. The role of phosphorus in the Eutrophication of receiving water: A review. J. Environ. Qual. 27:261-266. doi:10.2134/ jeq1998.00472425002700020004x

Correll, D.L. 1997. Buffer zones and water quality protection: General principles. In: N.E. Haycock, T.P. Burt, K.W.T. Goulding, and G. Pinay, editors, Buffer zones: Their processes and potential in water protection. Quest Environmental, Hertfordshire, UK. p. 7-20.

Darch, T., M.S.A. Blackwell, J.M.B. Hawkins, P.M. Haygarth, and D. Chadwick. 2014. A meta-analysis of organic and inorganic phosphorus in organic fertilizers, soils, and water: Implications for water quality. Crit. Rev. Environ. Sci. Technol. 44(19):2172-2202. doi:10.1080/10643389.2013.790752

Defra. 2013. Fertiliser manual (RB209). https://www.gov.uk/government/ publications/fertiliser-manual-rb209 (accessed 16 Feb. 2015).

Dillaha, T.A., R.B. Reneau, S. Mostaghimi, and D. Lee. 1989. Vegetative filter strips for agricultural nonpoint source pollution-control. Trans. ASAE 32(2):513519. doi: $10.13031 / 2013.31033$

Dorioz, J.M., D. Wang, J. Poulenard, and D. Trevisan. 2006. The effect of grass buffer strips on phosphorus dynamics: A critical review and synthesis as a basis for application in agricultural landscapes in France. Agric. Ecosyst. Environ. 117(1):4-21. doi:10.1016/j.agee.2006.03.029

Findlay, D.C., G.J.N. Colborne, D.W. Cope, T.R. Harrod, D.V. Hogan, and S.J. Staines. (1984). Soils and their use in South West England. SSEW, Harpenden, UK

Glæsner, N., C. Kjaergaard, G.H. Rubæk, and J. Magid. 2011a. Interactions between soil texture and placement of dairy slurry application: I. Flow characteristics and leaching of nonreactive components. J. Environ. Qual. 40:337-343. doi: $10.2134 /$ jeq2010.0317

Glæsner, N., C. Kjaergaard, G.H. Rubæk, and J. Magid. 2011b. Interactions between soil texture and placement of dairy slurry application: II. Leaching of phosphorus forms. J. Environ. Qual. 40:344-351. doi:10.2134/jeq2010.0318

Guan, X.H., G.H. Chen, and C. Shan. 2005. Competitive adsorption between orthophosphate and other phosphates on aluminum hydroxide. Soil Sci. 170(5):340-349. doi:10.1097/01.ss.0000169908.79614.db

Hahn, C., V. Prasuhn, C. Stamm, and R. Schulin. 2012. Phosphorus losses in runoff from manured grassland of different soil $\mathrm{P}$ status at two rainfall intensities. Agric. Ecosyst. Environ. 153:65-74. doi:10.1016/j.agee.2012.03.009

Harrod, T.R., and D.V. Hogan. 2008. The soils of North Wyke and Rowden. http:// www.rothamsted.ac.uk/sites/default/files/SoilsNWRowden.pdf (accessed 3 Dec. 2012).

Hayes, J.E., A.E. Richardson, and R.J. Simpson. 1999. Phytase and acid phosphatase activities in extracts from roots of temperate pasture grass and legume seedlings. Aust. J. Plant Physiol. 26(8):801-809. doi:10.1071/PP99065

Haygarth, P.M., and A.N. Sharpley. 2000. Terminology for phosphorus transfer. J. Environ. Qual. 29:10-15. doi:10.2134/jeq2000.00472425002900010002x

Heathwaite, A.L., and R.M. Dils. 2000. Characterising phosphorus loss in surface and subsurface hydrological pathways. Sci. Total Environ. 251-252:523-538. doi:10.1016/S0048-9697(00)00393-4
Hoffmann, C.C., C. Kjaergaard, J. Uusi-Kamppa, H.C.B. Hansen, and B. Kronvang. 2009. Phosphorus retention in riparian buffers: Review of their efficiency. J. Environ. Qual. 38:1942-1955. doi:10.2134/jeq2008.0087

Jensen, M.B., T.B. Olsen, H.C.B. Hansen, and J. Magid. 2000. Dissolved and particulate phosphorus in leachate from structured soil amended with fresh cattle faeces. Nutr. Cycl. Agroecosyst. 56(3):253-261. doi:10.1023/A:1009837520420

Jin, C.X., and M.J.M. Romkens. 2001. Experimental studies of factors in determining sediment trapping in vegetative filter strips. Trans. ASAE 44(2):277-288.

Kleinman, P.J.A., A.N. Sharpley, B.G. Moyer, and G.F. Elwinger. 2002. Effect of mineral and manure phosphorus sources on runoff phosphorus. J. Environ. Qual. 31:2026-2033. doi:10.2134/jeq2002.2026

Murphy, J., and J.P. Riley. 1962. A modified single solution method for determination of phosphate in natural waters. Anal. Chim. Acta 27(1):31-36. doi:10.1016/ S0003-2670(00)88444-5

Murphy, P.N.C. 2007. Lime and cow slurry application temporarily increases organic phosphorus mobility in an acid soil. Eur. J. Soil Sci. 58(3):794-801. doi:10.1111/j.1365-2389.2006.00869.x

Natural England and Defra. 2013. Environmental stewardship handbook, 4th ed. http://webarchive.nationalarchives.gov.uk/20140605090108/http:// publications.naturalengland.org.uk/publication $/ 2798159$ ? category $=45001$ (accessed Oct 2012).

Preedy, N., K. McTiernan, R. Matthews, L. Heathwaite, and P. Haygarth. 2001. Rapid incidental phosphorus transfers from grassland. J. Environ. Qual. 30:21052112. doi:10.2134/jeq2001.2105

Rausch, C., and M. Bucher. 2002. Molecular mechanisms of phosphate transport in plants. Planta 216(1):23-37. doi:10.1007/s00425-002-0921-3

Richardson, A.E., P.A. Hadobas, and J.E. Hayes. 2001. Extracellular secretion of Aspergillus phytase from Arabidopsis roots enables plants to obtain phosphorus from phytate. Plant J. 25(6):641-649. doi:10.1046/j.1365-313x.2001.00998.x

Rowland, A.P., and P.M. Haygarth. 1997. Determination of total dissolved phosphorus in soil solutions. J. Environ. Qual. 26:410-415. doi:10.2134/ jeq1997.00472425002600020011x

Shand, C.A., and S. Smith. 1997. Enzymatic release of phosphate from model substrates and $\mathrm{P}$ compounds in soil solution from a peaty podzol. Biol. Fertil. Soils 24(2):183-187. doi:10.1007/s003740050229

Shang, C., P.M. Huang, and J.W.B. Stewart. 1990. Kinetics of adsorption of organic and inorganic phosphates by short-range ordered precipitate of aluminium. Can. J. Soil Sci. 70(3):461-470. doi:10.4141/cjss90-045

Syversen, N. 2005. Effect and design of buffer zones in the nordic climate: The influence of width, amount of surface runoff, seasonal variation and vegetation type on retention efficiency for nutrient and particle runoff. Ecol. Eng. 24:483490. doi:10.1016/j.ecoleng.2005.01.016

Syversen, N., and H. Borch. 2005. Retention of soil particle fractions and phosphorus in cold-climate buffer zones. Ecol. Eng. 25(4):382-394. doi:10.1016/j. ecoleng.2005.06.005

Toor, G.S., L.M. Condron, B.J. Cade-Menun, H.J. Di, and K.C. Cameron. 2005. Preferential phosphorus leaching from an irrigated grassland soil. Eur. J. Soil Sci. 56(2):155-167. doi:10.1111/j.1365-2389.2004.00656.x

Turner, B.L., and P.M. Haygarth. 2005. Phosphatase activity in temperate pasture soils: Potential regulation of labile organic phosphorus turnover by phosphodiesterase activity. Sci. Total Environ. 344(1-3):27-36. doi:10.1016/j. scitotenv.2005.02.003

Turner, B.L., E. Frossard, and D.S. Baldwin. 2005. Appendix: organic phosphorus compounds in the environment. In: B.L. Turner, E. Frossard, and D.S. Baldwin, editors, Organic phosphorus in the environment. CAB International, Oxfordshire, UK. 381-390.

Ulen, B., M. Bechmann, J. Folster, H.P. Jarvie, and H. Tunney. 2007. Agriculture as a phosphorus source for eutrophication in the north-west European countries, Norway, Sweden, United Kingdom and Ireland: A review. Soil Use Manage. 23:5-15. doi:10.1111/j.1475-2743.2007.00115.x

Ullah, M.H., J. Abdul, and M.A. Khan. 1983. The influence of soil pH and texture on the adsorption of phosphorus by soils. Pak. J. Agric. Res. 4(1):41-46.

Withers, P.J.A., and P.M. Haygarth. 2007. Agriculture, phosphorus and eutrophication: A European perspective. Soil Use Manage. 23:1-4. doi:10.1111/j.1475-2743.2007.00116.x

Withers, P.J.A., R.A. Hodgkinson, A. Bates, and C.L. Withers. 2007. Soil cultivation effects on sediment and phosphorus mobilization in surface runoff from three contrasting soil types in England. Soil Tillage Res. 93(2):438-451. doi:10.1016/j.still.2006.06.004

Zall, D.M., D. Fisher, and M.Q. Garner. 1956. Photometric determination of chlorides in water. Anal. Chem. 28(11):1665-1668. doi:10.1021/ac60119a009 